\title{
Nástin vývoje textilního průmyslu ve Šternberku v letech 1850-1918
}

\author{
PAVLA DUBSKÁ
}

Dubská Pavla: Outline of the Development of the Textile Industry in Šternberk in the Years 1850-1918

For centuries, the town of Sternberk was closely associated with textile production which was an important part of the town's economy until the middle of the $20^{\text {th }}$ century. There had long been a tradition of producing linen fabrics but since the end of the $18^{\text {th }}$ century, the sales were increasingly threatened by competition from the more practical and cheaper cotton fabrics. In the first decades of the $19^{\text {th }}$ century, most weavers in Sternberk managed to switch to the production of pure cotton or blended fabrics and Šternberk thus relatively quickly became one of the most important centres of the cotton industry in Moravia. The present study attempts to outline the basic development trends of the textile industry in Šternberk from the 1850 s until the end of the First World War when the Industrial Revolution took place in most of its production phases. The fates of the most important companies are briefly described and attention is also paid to the production of silk fabrics which was carried out in Sternberk and the surrounding area by Viennese entrepreneurs since the middle of the $19^{\text {th }}$ century.

Key Words Entrepreneurship; Textile Industry; Sternberk; $19^{\text {th }}$ Century; $20^{\text {th }}$ Century doi.org/10.15452/Historica.2020.11.0004

Contact Univerzita PalackéhovOlomouci; pavla.dubska@gmail.com

Wenn wir uns dieser industriösen Stadt, diesem Lowell Mährens, von Olmütz aus nähern, werden wir durch die malerische Lage derselben und den wechselvollen, schönen Styl der Umgebung entzückt. ${ }^{1}$

Ohéralovo přirovnání města Šternberka k význačnému centru amerického textilního průmyslu, massachusettskému Lowellu, je sice poněkud nadsazené, nemění však nic na skutečnosti, že v 18. a 19. století se Šternberk řadil mezi významné lokality lnářského, později hlavně bavlnářského průmyslu na Moravě. Od počátku 20. století město tuto pozici ztrácelo. Zdejší textilní podniky stále více podléhaly tlaku modernější a kvalitnější konkurence, zahraniční, ale i závodů pracujících v Čechách. Mechanizace výroby postupovala pomalu a šternberské tkaniny se téměř výhradně uplatňovaly na vnitřních trzích habsburské monarchie. Kupříkladu ve srovnání se skoro stejně lidnatým Šumperkem, kde v roce 1911 pracovalo, nebo zde mělo alespoň své sídlo na 36 větších i menších závodů zabývajících se předením, tkaním (14 tkalcoven bylo mechanických) nebo úpravou látek, bylo ve Šternberku v roce 1913 činných 29 firem (u šesti tkalcoven máme doloženo 
použití mechanických stavů). ${ }^{2} \mathrm{~V}$ roce 1923 už se jednalo pouze o 22 podniků. ${ }^{3}$ Postupný úpadek šternberské textilní výroby může dokreslit také skutečnost, že po roce 1945 byla většina zde zbylých provozoven likvidována a jen minimum z nich bylo začleněno do některého $\mathrm{z}$ nově vzniklých národních podniků, které ale sídlily mimo území města Šternberka. ${ }^{4}$ Klesající význam zdejší textilní výroby zřejmě ovlivnil i menší zájem historiků a vlastivědných pracovníků o tuto důležitou součást dějin města. ${ }^{5}$

\section{Lnářský a bavlnářský průmysl}

Výroba látek byla od nepaměti nedílnou součástí městského hospodářství. Jan Ohéral kladl počátky tkalcovského cechu již do 14. století, kdy se ve městě ze lněné př́ize vyrábělo zejména surové nebělené plátno. V průběhu 15. století bylo vybudováno městské bělidlo a zavedeno barvení příze na hnědo a modro, díky čemuž se rozšířil sortiment zboží vyráběný zdejšími tkalcovskými mistry o kapesníky, kanafasy a trilichy. V roce 1632 tkalcovský cech zpř́isnil kontrolu vyrobených tkanin, kdy pouze zboží, které mělo správnou délku, kvalitu a trvanlivost barvy, bylo opatřeno cechovní pečetí a mohlo putovat na trhy, mj. do Vídně, Pešti a Debrecínu. Odtud se šternberské látky dostávaly dále do Haliče a Ruska. Tato praxe kontroly kvality se udržela až do roku 1821.

Od roku 1719 se pro barvení přízí začala používat také turecká červeň, čímž se šternberskému kanafasu, grádlu, šátkům a dalším tkaninám otevřela cesta na trhy v Itálii,

\footnotetext{
Podle sčítání lidu z roku 1910 žilo v Šumperku 13329 obyvatel a ve Šternberku 14601 obyvatel. Adreßbuch für die Stadt Mähr.-Schönberg. Mähr.-Schönberg 1911, s. 132, 135, 145, 150; Compass : Finanzielles Jahrbuch für Oesterreich-Ungarn 1913, 3/2. Wien 1912, s. 1915, 1994, 2007, 2143.

3 Adressbuch der Textil-Industrie der Nachfolgestaaten Österreich-Ungarns, ferner von Polen und Jugoslavien. Reichenberg 1923, s. 368-370.

$4 \quad$ V podstatě se jednalo pouze o firmu Heeg \& Friedmann, která v roce 1948 přešla do vlastnictví n. p. Slezské bavlnářské závody, Frýdek.

5 Svou roli zde jistě sehrál i problematický stav dochování a zpracování materiálů ve fondech Archiv města Šternberk a Okresní úrúad Šternberk, uložených ve Státním okresním archivu Olomouc. Písemnosti obou těchto fondů byly $\mathrm{z}$ velké části zničeny za druhé světové války, popř. se na nich podepsaly rozsáhlé skartace $\mathrm{z}$ počátku 20. století a z 50. let. Obdobně je tomu i v případě firemních fondů uložených v olomoucké pobočce Zemského archivu v Opavě. Rozsáhleji se tak dějinám šternberského textilního průmyslu věnovalo jen několik málo autorů. Ze starších prací jmenujme především novinové a časopisecké články Jana Ohérala (Sternberg, der Stadt der Weber. Moravia, 2. 9. 1839, s. 629-630; Tamtéž, 5. 9. 1839, s. 633-634; Die Industrie der Stadt Sternberg in ihren Anfängen und Fortschritten. Moravia, 27. 7. 1844, s. 305-307) a Karla Teucherta (Die Sternberger Weberei vor 60 Jahren. Deutsches Volksblatt für Mähren und Schlesien, 4. 6. 1932, s. 1-2; Tamtéž, 11. 6. 1932, s. 1; Tamtéž, 18. 6. 1932, s. 1-2; Tamtéž, 25. 6. 1932, s. 1; Tamtéž, 2. 7. 1932, s. 1; Tamtéž, 9. 7. 1932, s. 1-2; Tamtéž, 16. 7. 1932, s. 1-2; Tamtéž, 23. 7. 1932, s. 1-2; Tamtéž, 30. 7. 1932, s. 1-2; Tamtéž, 6. 8. 1932, s. 1; Tamtéž, 13. 8. 1932, s. 1-2; Tamtéž, 20. 8. 1932, s. 1-2), publikace Christiana d'Elverta (Zur Cultur-Geschichte Mährens und Oesterr. Schlesiens, 3 : Geschichte der Woll-, Leinen-, Baumwoll- und Seidenwaaren, der Bier-, Branntwein-, Essig- und Zuckerfabrikation und des neuesten Bergbaues in Mähren und Oesterr. Schlesien. Brünn 1870) a Wilhelma Stiefa (Geschichte der Stadt Sternberg in Mähren. Sternberg 1894, přeprac. a dopl. vydání Schaffhausen 1934; Topographie des politischen Bezirkes Sternberg in Mähren. Sternberg 1896). Z novějších pak monografie Františka Mainuše (Plátenictví na Moravě a ve Slezsku v XVII. a XVIII. století. Ostrava 1959; Vlnařství a bavlnářství na Moravě a ve Slezsku v XVIII. století. Praha 1960) a Jana Janáka (Vlastivěda moravská: Dějiny Moravy, 3/1: Hospodářský rozmach Moravy 1740-1918. Brno 1999). V posledních letech byla šternberskému textilnímu průmyslu věnována určitá míra pozornosti v souvislosti s výzkumem společenských elit (MALíŘ, Jiří a kol.: Biografický slovník poslanců moravského zemského sněmu v letech 1861-1918. Brno 2012) a s projekty, které se zaměřovaly na průzkum a ochranu průmyslového dědictví (BERAN, Lukáš a kol.: Technické památky v Čechách, na Moravě a ve Slezsku, I-IV. Praha 2002-2004; TITÍŽ: Industriální topografie: Olomoucký kraj. Praha 2013).
} 
Konstantinopoli a odtud dále na východ. ${ }^{6}$ Bylo tak odstartováno období největšího rozmachu šternberské lnářské výroby. Ve 30. letech 18. století čítal tkalcovský cech 60 městských a dva inkorporované venkovské mistry. V roce 1751 jejich počet stoupl na 100 , pro něž pracovalo 121 tovaryšů, přičemž bohatí mistři si drželi více tovaryšů a mohlo pro ně pracovat až 25 tkalcovských stavů. Pro rok 1770 stanovil František Mainuš počet mistrů na 163 s 273 tovaryši a v roce 1799 na 395 mistrů pracujících na 720 stavech. K tomu připočítal ještě dalších 84 pláteníků se 162 stavy, kteří tkali v okolních vesnicích. ${ }^{7} \mathrm{~V}$ roce 1786 bylo vyrobeno 31546 ks látek, zejména kanafasu a grádlu, a 54559 tuctů šátků, o rok později 32236 kusů kanafasu, grádlu aj. a 47244 tuctů šátků. ${ }^{8}$

Pro úplnost uved'me, že kromě lnu se zde zpracovávala také vlna. V roce 1728 ve Šternberku pracovalo 24 mistrů soukeníků na 24 stavech, kteří ročně vyrobili 200 ks suken. Nejednalo se však o nijak závratné množství, pokud tato čísla srovnáme např. s tehdy menším Šumperkem, kde pracovalo 46 mistrů soukeníků na 46 stavech, jenž ročně vyrobili na 1150 ks suken. ${ }^{9}$

Na konci 18. století ale započal pokles zdejší lnářské produkce. Za hlavní příčinu Jan Ohéral označil především politickou situaci ve Francii, která nakonec vyústila ve vojenský konflikt probíhající ve velké části Evropy, jenž měl pochopitelně negativní dopad na obchod. ${ }^{10} \mathrm{~V}$ oblasti výroby látek se v tuto dobu také čím dál více prosazovaly bavlněné tkaniny, které byly praktičtější a hlavně cenově dostupnější. ${ }^{11}$ Šternberské lněné zboží bylo nejvíce ohroženo konkurencí bavlněných látek z Anglie, Německa, Nizozemí, Saska a také z Čech, kde se bavlnářství velmi rychle rozvíjelo. Svou roli zde sehrálo i několik slabých úrod lnu, jež zvedly cenu lněné příze. ${ }^{12}$ Tím se snížily výdělky místních tkalců, kteří vyráběli spíše jednoduché tkaniny, které nacházely odbyt na méně náročných trzích, kde více než kvalita zajímala spotřebitele cena. ${ }^{13}$ Nabízela se tak možnost přechodu na tkaní bavlněných látek, který byl motivován př́íslibem vysokého zisku a rychlého obratu investic. ${ }^{14}$

Jako první si nechali do Šternberka přivést anglickou bavlněnou př́zi tkalcovští mistři bratři Pawlikové v roce 1802, z níž vyrobili první modré a červené šátky. Postupně na výrobu bavlněných látek přecházeli další a další tkalci. Řada z nich zhotovovala kromě čistě bavlněných látek také tkaniny směsové (s přídavkem lněné příze), $v$ menší míře čistě lněné. ${ }^{15} \mathrm{Z}$ hlediska technického nepředstavoval přechod $\mathrm{k}$ tkaní bavlněných látek

\footnotetext{
6 OHÉRAL, J.: Die Industrie, s. 305-306.

7 MAINUŠ, F.: Plátenictví, s. 87, 109.

8 D'ELVERT, Ch.: Zur Cultur-Geschichte, s. 255.

9 MAINUŠ, F.: Vlnařství, s. 39, 43.

10 OHÉRAL, J.: Die Industrie, s. 306.

11 JINDRA, Zdeněk - JAKUBEC, Ivan a kol.: Hospodářský vzestup českých zemí od poloviny 18. století do konce monarchie. Praha 2015, s. 260.

12 OHÉRAL, J.: Die Industrie, s. 306.

13 Analogická situace probíhala v obvodu olomoucké obchodní a živnostenské komory například na Místecku. K tomu blíže MYŠKA, Milan: Lnářský a bavlnářský průmysl na Frýdecku a Místecku do počátku tovární výroby : Opožděná industrializace. Frýdek-Místek 2013.

14 JINDRA, Z. - JAKUBEC, I. a kol.: Hospodářský vzestup, s. 260.

15 OHÉRAL, J.: Die Industrie, s. 306. Výroba lněných tkanin na Šternbersku zcela nevymizela i díky tomu, že se zde i v nadcházejících desetiletích len stále pěstoval. Kupříkladu v roce 1852 bylo lnem ve šternberském stejně jako šumperském berním okrese osazeno 6 \% zemědělské půdy, což ve šternberském okrese činilo 10607 měřic a v šumperském 7807 měřic. Bericht der Handels- und Gewerbekammer in Olmütz an das hohe k. k. Ministerium im Jahre 1852. Olmütz 1853.
} 
výraznější problém. Výrobní postup byl víceméně obdobný, stačilo tedy provést jen několik drobných úprav na stávajících stavech, na nichž se doposud tkaly čistě lněné látky. ${ }^{16}$

Na Šternbersku vyráběný sortiment brzy zahrnoval širokou škálu bavlněných šátků a kapesníků (modrých, modrobílých, bíločervených), dámská sukna či drobně vzorkované kanafasy. ${ }^{17}$ Zpočátku se jednalo spíše o hrubé tkaniny, jemnější zboží se začalo vyrábět po roce 1818, kdy z iniciativy lékárníka Wilhelma Nohy místní cech zřídil novou úpravnu používající chemickou metodu bílení. Strojová bavlněná příze se dovážela z Rakouska, Čech a Elberfeldu, na území Olomouckého kraje se ručním předením bavlny zabývalo venkovské obyvatelstvo v okolí Prostějova, Náměště na Hané a Plumlova. Hotové zboží směrovalo ze Šternberka do Polska, Vídně, ${ }^{18}$ Itálie, Levanty, Uher a některých švýcarských kantonů. ${ }^{19}$

Značný rozmach zdejšího bavlnářského průmyslu přinesla druhá polovina 20. let 19. století, kdy mj. došlo k zavedení tzv. rychloběžného člunku a uplatnění inovací v oblasti barvení látek. ${ }^{20}$ Rozšířila se škála používaných barev o hnědou, černou, fialovou, žlutou, zelenou či šedou. Kromě šátků se vyráběly různé druhy prostírání, šatovek, kanafasů, bavlněných pláten (Scheckelů, též Schöcklů), rypsů, keprů či tapetových látek. ${ }^{21} \mathrm{~V}$ roce 1839 zařadil Gregor Wolny tehdy téměř sedmitisícový Šternberk mezi přední centra bavlnářské výroby na Moravě. ${ }^{22} \mathrm{~K}$ dalším významným lokalitám v té době patřil Prostějov, Místek, Frenštát a Svitavy. ${ }^{23}$ Wolny ve Šternberku napočítal na 1508 řemeslníků, přičemž tkaním se podle něj živilo 1200 z nich. Dva podniky vlastnily tovární oprávnění. ${ }^{24}$ Celkově odhadoval, že ve městě a okolí se tkalcovskému řemeslu věnovalo zhruba 10000 osob. ${ }^{25}$

Vceňovací operáty uvádějí pro město Šternberk k roku 18442278 osob zabývajících se výrobou bavlněných a směsových tkanin, z toho bylo 278 zdaněných mistrů, 1000 samostatných dělníků ve mzdě, 600 tovaryšů, 300 učňů a 100 žen. Roční produkce byla odhadována na 309874 kusů v hodnotě 1549370 zlatých k. m., přičemž odbyt nacházela především ve Vídni, Uhrách, Haliči a Slezsku. Průměrně se spotřebovalo 101000 centnýřù bavlněné a 870 centnýřů lněné příze. ${ }^{26}$ Výroba byla v drtivé většině organizována formou nákladnického systému ${ }^{27}$, který se zde rozvíjel již v rámci lnářské výroby v 18 . století. ${ }^{28}$

\footnotetext{
16 MYŠKA, M.: Lnářský a bavlnářský průmysl, s. 46.

17 OHÉRAL, J.: Die Industrie, s. 306.

18 D’ELVERT, Ch.: Zur Cultur-Geschichte, s. 387.

19 OHÉRAL, J.: Die Industrie, s. 306.

20 Zemský archiv v Opavě, pobočka Olomouc (dále ZAO-Ol), fond Obchodní a živnostenská komora Olomouc (dále OŽK Olomouc), inv. č. 1965, kart. 223.

21 OHÉRAL, J.: Die Industrie, s. 307.

22 WOLNY, Gregor Thomas: Die Markgrafschaft Mähren, topographisch, statistisch und historisch geschildert, 5 : Olmützer Kreis. Brünn 1839, s. 742.

23 Tafeln zur Statistik der österreichischen Monarchie für das Jahr 1841. Wien 1844, Tafel 51.

24 Firma J. Gromann \& Sohn získala v roce 1833 jednoduché tovární oprávnění, firma Norbert Langer \& Söhne v roce 1821 formální zemské tovární oprávnění.

25 WOLNY, G. T.: Die Markgrafschaft, s. 742-743.

26 Moravský zemský archiv v Brně (dále MZA Brno), fond D8 Stabilní katastr - vceňovací operáty, sign. 2537, kart. 918.

27 K tomu blíže zejména MYŠKA, Milan: Nákladnický systém a decentralizovaná manufaktura : Teoretická úvaha o podstatě těchto ekonomických kategorií na příkladu textilního průmyslu. In: I. setkání historiků textilního a oděvního průmyslu. Z dějin textilu, suppl. 4. Ústí nad Orlicí 1985, s. 84-104.

28 MAINUŠ, F.: Plátenictví, s. 99.
} 
Zámožnější mistři sídlící ve městě zadávali práci dalším mistrům, tovaryšům a pomocným dělníkům, a to nejen ve Šternberku, ale i ve vzdálenějším okolí, např. v Moravském Berouně, Dvorcích, Budišově nad Budišovkou, v Konici či Šebetově. Sami se pak často zabývali pouze obstaráváním a úpravnou bavlněné příze, barvením, přejímkou hotových tkanin a jejich odbytem. Pro jednoho mistra mohlo pracovat dvacet, ve výjimečných případech i 400 stavů. ${ }^{29}$ Úhrnně se tak na výrobě šternberských tkanin mohlo podílet, jak naznačoval již Wolny, na 10000 osob.

Produkci bavlněných stuh se ve městě v roce 1844 věnoval jeden mistr spolu se šesti pomocníky. Ročně zhotovili na šesti stavech 25000 kusů stuh o šířce $1 / 4$ až $2 \frac{2}{4}$ délce osmnáct loktů při spotřebě čtrnácti centnýřů bavlněné a dvou centnýřủ lněné prríze. Toto zboží se prodávalo v prostoru Moravy, popř. směřovalo do Slezska. Kromě bavlny a lnu se v první polovině 40. let ve Šternberku stále zpracovávala i vlna, pocházející částečně z Uher, částečně z Moravy a Slezska. Ročně vyrobilo 25 zdaněných mistrů ze 40 centnýřů vlny na 800 kusů šátků a 100 kusů moltonu. Soukenický cech provozoval na Olomouckém předměstí valchu, kterou obsluhoval jeden mistr spolu s jedním tovaryšem a jíž ročně prošlo 800 ks sukna. ${ }^{30}$

K nejvýznamnějším firmám vznikajícím ve 20. až 40. letech 19. století patřily podniky Carl Fiedler (zal. 1820), Franz Riedl (1820), Franz Chytil (1827), L. Jahn \& Sohn (1830), E. \& M. Mittag (1830), Gebrüder Gröger (1832), Franz Langer (1832), Joh. Gromann \& Sohn (1833), Carl Augustin (1840), Josef Fiedler (1840), Johann Faukal (1842), Alois Jeuthner \& Söhne (1842), Franz Jirgens (1842), Carl Mikulaschek \& Sohn (1844) a A. Münch (1845). ${ }^{31}$

V této době se pracovalo především na jednoduchých tkalcovských stavech, první žakárové stavy přivezl do Šternberka pravděpodobně Karl Langer v roce $1832 .{ }^{32}$ Karl Langer spolu se svým bratrem Franzem vedli od roku 1848 tkalcovnu lněného a bavlněného zboží firmy Norbert Langer \& Söhne, ${ }^{33}$ jejíž počátky byly tradičně kladeny do roku 1792. Tehdy se Karlův a Franzův otec Norbert Langer stal tkalcovským mistrem ve Šternberku a začal pracovat na vlastní účet.

Langerové patřili ke starobylým moravským rodům, jejichž nejstarší stopu můžeme vysledovat až v 15. století nedaleko Svitav. Rodinná tkalcovská tradice měla počátek u Simona Langera, který v polovině 17. století obdržel mistrovské právo ve Svitavách. Do města Šternberka se rodina dostala prostřednictvím tkalce Andrease Langera, jenž sem přivandroval v roce 1754 . O rok později získal mistrovské právo a zakoupil dům na

29 OHÉRAL, J.: Sternberg, 2.9.1839 s. 630; MZA Brno, D8 Stabilní katastr - vceňovací operáty, sign. 7, kart. 2; Tamtéž, sign. 1218, kart. 461; Tamtéž, sign. 1604, kart. 592; Tamtéž, sign. 1701, kart. 628; Tamtéž, sign. 1826, kart. 671; Tamtéž, sign. 2342, kart. 849; Tamtéž, sign. 2537, kart. 918.

30 MZA Brno, fond D8 Stabilní katastr - vceňovací operáty, sign. 2537, kart. 918.

31 TEUCHERT, K.: Die Sternberger, 4. 6. 1932, s. 1-2.

32 Jméno Karla Langera uvádí jak Jan Ohéral, tak i předválečný místostarosta Německé Libiny (dnes Libina), tamější kronikář a vlastivědný pracovník Ernst Federmann (Die Leinen-, Baumwoll- und Kunstseidenwarenfabrik der Firma Norbert Langer \& Söhne, s. 405-416; text je součástí konvolutu článků a podkladů k dějinám Německé Libiny, které Ernst Federmann předal představitelům obce krátce před svým odsunem do Německa v záŕí roku 1946. Jednotlivé stránky očísloval první poválečný libinský kronikář František Žužka. Součástí konvolutu jsou také fotografie Alberta Langera, ručních stavů, provozu místní tkalcovny a několika tkanin. Uloženo ve Státním okresním archivu Šumperk, fond Archiv obce Horní Libina). Pouze Karl Teuchert zmiňuje jako prvního člověka, který do Šternberka přivezl žakárový stav, tkalce barchetu Nikolause Köhlera. TEUCHERT, K.: Die Sternberger Weberei, 4. 6. 1932, s. 2.

33 ZAO-Ol, fond Krajský soud Olomouc - firemní spisy (dále KS Olomouc), inv. č. 4054, sign. AX 372, kart. 209. 
předměstí č. 25, kde si zřídil vlastní dílnu. V té se vyučil také jeho syn Norbert, zakladatel firmy Norbert Langer \& Söhne. ${ }^{34}$

Zpočátku Norbert ve své dílně vyráběl především lněný kanafas a grádl, anglický kanafas a šátky či hladké plátno. ${ }^{35} \mathrm{Od}$ počátku zadával práci také námezdním tkalcům, kolem roku 1800 pro něj pracovalo dvacet stavů, o dvě desítky let později jich bylo již $78 .{ }^{36} \mathrm{~V}$ roce 1820 mu bylo propůjčeno jednoduché a o rok později formální zemské tovární oprávnění k výrobě lněného a bavlněného zboží, které ho mj. opravňovalo používat označení c. $\mathrm{k}$. privilegovaná továrna. Norbert Langer byl pravděpodobně vůbec první mezi šternberskými tkalci, který toto oprávnění získal. V tomto roce do svého podnikání přibral své syny Karla a Franze a vytvořil tak veřejnou obchodní společnost Norbert Langer \& Söhne, ${ }^{37}$ kterou nechal zaprotokolovat u brněnského směnečného soudu. Do obchodního rejstř́ku vedeného u Krajského soudu v Olomouci byla firma zapsána v roce $1852 .{ }^{38}$ Již ve 20. letech společnost provozovala také prodejní sklad ve Vídni. ${ }^{39}$

Dobrý finanční vývoj podniku umožnil Langerům v této době zakoupit ve městě další budovu, stejně jako tzv. klášterní zahradu, kde v 60. letech vystavěli obytný a obchodní dům. Jak již bylo uvedeno výše, Norbertův syn Karl v roce 1832 přivezl do Šternberka první žakárové stavy, které Langerům umožnily rozšířit vyráběný sortiment o nové vzorované zboží. Produkce podniku rychle narůstala a v roce 1835 pro něj pracovalo 150 stavů. $\mathrm{V}$ této době firma zrrídila také vlastní úpravnu a bělidlo, když přebudovala staré bělidlo v Oskavě (dnes okres Šumperk). ${ }^{40} \mathrm{~V}$ roce 1843 se roční produkce podniku pohybovala mezi 20000 až 22000 kusů čistého a směsového bavlněného zboží o délce 30 loktů a 5000 až 6000 kusů Iněného zboží. ${ }^{41}$ Kvalita Langrových výrobků byla záhy oceněna bronzovou medailí na hospodářské výstavě konané ve Vídni v roce $1845 .{ }^{42}$

V průběhu 50. a 60. let bylo investováno především do oskavského bělidla a apretovny, což úzce souviselo s postupnou modernizací a mechanizací této části výrobního procesu. ${ }^{43}$ Od roku 1863 se výroba ze Šternberka začala postupně přesouvat do Německé Libiny (dnes Libina, okres Šumperk), v níž a jejímž okolí se nacházela kvalitní a přitom levná pracovní síla. Byla zde vybudována ruční tkalcovna, kde se na žakárových stavech zhotovovalo zejména jemné a damaškové zboží, damaškové ubrusy a prostírání. ${ }^{44}$

V roce 1873 firma prezentovala své výrobky na světové výstavě ve Vídni, kde se jejím zástupcům podařilo navázat kontakty se zámořskými obchodníky a rozšířit tak okruh

\footnotetext{
34 FEDERMANN, E.: Die Leinen-, Baumwoll- und Kunstseidenwarenfabrik, s. 405-411.

35 Norbert Langer \& Söhne, Sternberg, Oskau, Deutsch-Liebau und Nieder Dřewitsch. In: Die Gross-Industrie Oesterreichs, IV. Wien 1898, s. 322-323.

36 FEDERMANN, E.: Die Leinen-, Baumwoll- und Kunstseidenwarenfabrik, s. 410.

37 Norbert Langer \& Söhne, s. 322-323.

38 ZAO-Ol, fond KS Olomouc, sign. Q 1852/16, kart. 171.

39 Wiener Stadt- und Landesarchiv, fond Merkantil- und Wechselgericht, Faszikel 3 - Firmenakten, 1. Reihe, L 142 .

40 FEDERMANN, E.: Die Leinen-, Baumwoll- und Kunstseidenwarenfabrik, s. 410-411.

41 MZA Brno, fond D8 Stabilní katastr - vceňovací operáty, sign. 1826, kart. 671.

42 SLOKAR, Johann: Geschichte der österreichischen Industrie und ihrer Förderung unter Kaiser Josef I. Wien 1914, s. 379.

43 K tomu blíže DOHNAL, Miloň: Průmyslová revoluce a počátky dělnického hnutí v severomoravské plátenické oblasti. Ostrava 1973.

44 FEDERMANN, E.: Die Leinen-, Baumwoll- und Kunstseidenwarenfabrik, s. 412.
} 
zemí, do kterých bylo zboží exportováno. ${ }^{45}$ Doposud se zboží prodávalo především přes trhy v Brně, Pešti, Debrecínu, Vídni a Štýrském Hradci a vyváželo se na Balkán a do Itálie. ${ }^{46}$ V70. letech se počet stavů pracujících v Langerových závodech pohyboval okolo 300, do roku 1885 stoupl na 400, o rok později na 600. Také ruční tkalcovna bavlny, do té doby provozovaná ve Šternberku, přešla na mechanické stavy, když byla v roce 1895 přemístěna do Nízkého Dřevíče u Hronova v Čechách (dnes součást Hronova, okres Náchod). ${ }^{47}$

V roce 1892, kdy firma slavila 100 let své existence, byly Langrovy závody tvořeny bělidlem, úpravnou, obytným a obchodním domem v Oskavě, dvěma obytnými a obchodními domy ve Šternberku, jedním obytným a obchodním domem a jedním továrním objektem v Německé Libině. Zde bylo v letech 1892-1895 instalováno 150 mechanických stavů a dalších 60 pracovalo pro firmu v Žabokrcích u Hronova. Kromě toho Langerové zadávali práci dalším zhruba 500 ručních tkalců.

Na počátku 20. století bylo výrazně investováno do výrobní kapacity libinské továrny i oskavského bělidla a úpravny. V roce 1912 byl počet mechanických tkalcovských stavů nacházejících se v továrních prostorách v Německé Libině navýšen o dalších 290 kusů. Zároveň byla v roce 1902 zakoupena mechanická tkalcovna v Ústí nad Orlicí se 100 stavy, v roce 1918 byla získána mechanická tkalcovna bavlny, šlichtovna a soukárna v Roztokách-Kruhu (okres Semily) se 476 stavy. Po roce 1918 bylo veškeré řízení rozsáhlého podniku přeneseno z Vídně do Německé Libiny. Zde byly provozy dále rozšiřovány a modernizovány, od roku 1925 se zde zpracovávalo i umělé hedvábí, využívané především na výrobu čajového a kávového prostírání. Jen pro doplnění uved'me, že v roce 1930 čítaly Langerovy závody čtyři mechanické tkalcovny s 1016 stavy, dvě úpravny a jedno bělidlo příze a zboží, jednu mechanickou šicí dílnu a pletárnu, jednu barvírnu a tiskárnu, jeden ateliér a malířství dezénů a jednu továrnu na výrobu obalových materiálů. Celkově firma zaměstnávala mezi 2400 a 2800 osobami. Vyráběla se široká škála lněného, bavlněného i hedvábného zboží, jako bylo např. prostírání, prádlo pro hotely, plovárny, sanatoria, lodní a železniční společnosti, tkaniny pro armádu. ${ }^{48}$ Definitivně bylo sídlo společnosti přeneseno ze Šternberka do Německé Libiny v roce $1942 .{ }^{49}$

Ve firmě Norbert Langer \& Söhne byl zaměstnán nespočet rodinných příslušníků. Řada z nich byla činná i ve veřejném životě. V souvislosti s městem Šternberkem nesmíme opomenout především Adolfa Langera sen., který do rodinné firmy vstoupil pravděpodobně v roce 1865 a o dva roky později se stal veřejným společníkem. ${ }^{50} \mathrm{~V}$ roce 1862 stál u vzniku šternberského tělocvičného spolku, v jehož vedení se aktivně angažoval dalších devět let. Byl také dlouholetým členem obecního výboru. Od roku 1868 až do své smrti v roce 1909 zasedal ve výboru městské spořitelny, v jejímž čele stál od roku 1872. Za své veřejné aktivity byl oceněn rytířským křižem Řádu Františka Josefa. ${ }^{51}$ Na tomto

\footnotetext{
Norbert Langer \& Söhne, s. 322-323.

46 D'ELVERT, Ch.: Zur Cultur-Geschichte, s. 265.

47 Norbert Langer \& Söhne, s. 322-323; ZAO-Ol, fond KS Olomouc, inv. č. 4054, sign. A X 372, kart. 209. Tento pobočný závod byl z obchodního rejstř́ku vedeného u Krajského soudu v Olomouci vymazán v roce 1909.

48 FEDERMANN, E.: Die Leinen-, Baumwoll- und Kunstseidenwarenfabrik, s. 413-414.

49 ZAO-Ol, fond KS Olomouc, inv. č. 4054, sign. A X 372, kart. 209.

51 Deutsches Volksblatt für Mähren und Schlesien, 27.1.1909, s. 4.
}

50 Tamtéž. 
místě zmiňme ještě Wilhelma Langera, který byl veřejným společníkem firmy v letech 1872-1893. Ten působil jako ředitel Rakousko-uherské banky ve Vídni. ${ }^{52}$

Avšak k nejvýraznějším osobnostem rodinného podnikání patřil bezesporu, vedle zakladatele firmy Norberta Langera $(† 1848)$, jeho pravnuk a synovec výše zmíněného Adolfa sen., Adolf Langer jun., který se stal veřejným společníkem firmy v roce 1893 a byl jím až do své smrti v roce $1934 .^{53}$ Výraznou měrou se podílel na jejím rozvoji, kupř. když v roce 1897 jako jeden z prvních v Evropě zavedl pro výrobu ubrusů a prostírání žakárový stav se systémem nekonečných děrovacích karet, jenž si nechal v 80. letech 19. století patentovat Francouz Jules Verdol. Velký důraz kladl Langer na kvalitu vzorů, proto se zasadil o to, aby firma zaměstnala dva akademické malíře a více než dvacet vzorkařu a 40 malířek. Byl komerčním radou a předsedou šumperské pobočky Svazu německého průmyslu v Československu (Hauptverband der Deutschen Industrie der Tschechoslowakei) ${ }^{54}$ a viceprezidentem Akciové společnosti lnářských tkalců (Aktiengesellschaft der Leinenweber). ${ }^{55} \mathrm{~V}$ letech 1918-1919 působil jako starosta Německé Libiny, jejímž byl čestným občanem. ${ }^{56}$

Patrně nejlepší představu o postavení a vývoji textilního průmyslu na Šternbersku si můžeme udělat pro 50. léta 19. století, především díky dochovaným materiálům z činnosti Obchodní a živnostenské komory v Olomouci. Tehdy se na Moravě a ve Slezsku nacházelo celkem sedm velkých bavlnářských oblastí, kromě Šternberka se jednalo o Svitavy a Prostějov, Moravskou Třebovou spolu s Dolními Kounicemi, Ivančicemi a Židlochovicemi, Červenou Vodu, Místek a Frýdek, Frenštát pod Radhoštěm a Jeseník. ${ }^{57}$

Především na počátku 50. let se moravský bavlnářský i lnářský průmysl potýkal s krizí, jejíž první známky se objevily již v předchozí dekádě. ${ }^{58} \mathrm{Na}$ vině bylo všeobecné zvyšování cen surovin a polotovarů a rostoucí náklady na mzdy, které byly zapříčiněny především zdražováním potravin. V př́padě bavlnářského průmyslu velkou roli sehrálo také omezení podomního obchodu v Uhrách, které byly hlavními odběrateli nejen šternberských tkanin. Obecně lze říci, že docházelo ke snižování spotřeby a tím i cen hotových výrobků, obchod vázl téměř ve všech odvětvích hospodářského života a podnikatelům se nedostávalo kapitálu. Ve skladech jednotlivých výrobců i na trzích se začaly hromadit látky vyrobené v letech 1849-1851, které navíc byly čím dál obtížněji schopné konkurovat kvalitnější, zejména anglické a belgické produkci.

V roce 1852 se ve šternberském berním okrese vyrobilo 53315 kusů lněných a pololněných tkanin z celkového počtu 472126 kusů lněných, pololněných a konopných látek utkaných ve lnářských okresech obvodu olomoucké obchodní a živnostenské komory. $\mathrm{V}$ případě bavlněných tkanin se zhotovilo 108380 kusů bavlněných látek z celkového počtu 1231275 kusů. Obchod zde celkově poklesl o 20 \% oproti roku 1851, v důsledku čehož výroba na začátku roku 1853 poklesla o jednu třetinu. Hlavní sortiment tehdy

\footnotetext{
52 HELLER, Hermann: Mährens Männer der Gegenwart, 4. Brünn 1890, s. 95.

53 ZAO-Ol, fond KS Olomouc, inv. č. 4054, sign. A X 372, kart. 209.

54 MARSCHNER, Erhard: Langer, Adolf Richard. In: Neue Deutsche Biographie, 1982, sv. 13. Online, cit.

2. 8. 2019, dostupné na https://www.deutsche-biographie.de/sfz48048.html\#ndbcontent.

55 Compass. Finanzielles Jahrbuch 1926, 2 : Česchoslovakei. Prag 1926.

56 Nordmährischer Grenzbote, 15.9.1934, s. 9.

57 JANÁK, Jan: Vlastivěda moravská:Dějiny Moravy, 3/1: Hospodářský rozmach Moravy 1740-1918. Brno 1999, s. 108 .

58 Tamtéž, s. 110.
} 
tvořily šatovky, ložní prádlo, žíněnková a kalhotová látka a šátky. ${ }^{59} \mathrm{O}$ rok později bylo utkáno 67256 kusů lněných a pololněných látek, především pláten, Schöckelů, kanafasu, damašků, cvilichu, trilichu, podšívkového plátna, rypsů, ložního a stolního prádla, z celkového počtu 644596 kusů. Bavlněných látek, zejména bavlněných Schöckelů a plátna, se vyrobilo 138847 kusů z celkového objemu 1244378 kusů tkanin, k čemuž musíme ještě připočítat 26688 tuctů šátků (z celkových 29344 tuctů) a 210 tuctů ručníků (z celkových 240 tuctů). Na první pohled se množství látek vyrobených v roce 1853 zdá vyšší než v roce 1852, výše jsme však konstatovali celkový pokles výroby. Zkreslení způsobuje délka jednoho kusu látky. Zatímco v roce 1852 se počítalo s průměrnou délkou od 54 do 70 loktů, v roce 1853 se délka jednoho kusu tkaniny udávala v hodnotě 30 loktů. ${ }^{60}$

Údaje o počtu tkalců a činných stavů v bavlnářském a lnářském průmyslu v 50 . letech 19. století se značně rozcházejí podle toho, z jakých zdrojů olomoucká obchodní a živnostenská komora ve svých statistikách vycházela. Stejně jako úředníci komory i Jan Janák ${ }^{61}$ považoval za nejrealističtější čísla udávaná jednotlivými cechy. Podle nich bylo v berním okrese Šternberk v bavlnářském průmyslu zaměstnáno v roce 185210834 osob z celkového počtu 44272 osob, o rok později 9137 osob z celkových 39062 . Pracovalo se na 5248 stavech v roce 1852 (celkem 28 250), resp. na 4328 stavech (celkem 23308) v roce $1853 .^{62}$

Navzdory neprríznivé hospodářské situaci nejen textilního průmyslu vznikla v průběhu 50. let ve Šternberku celá řada nových firem, za všechny jmenujme Heeg, Schottik \& Friedmann (zal. 1850), Johann Homma (1850), Anton Mischke (1850), Gebrüder Hoppenberger (1851). ${ }^{63}$ Co se týče velikosti podniků pracujících v této době na Šternbersku, jednalo se spíše o závody středního rozsahu, které zaměstnávaly v průměru dvacet až 100 osob. ${ }^{64}$

Podrobnější údaje o počtech stavů a zaměstnanců máme pro toto období k dispozici pouze u několika firem. Společnost Heeg, Schottik \& Friedmann, od roku 1857 nesoucí název Heeg \& Friedmann, vznikla ve Šternberku z iniciativy zdejšího tkalcovského mistra Antona Heega. Ten v roce 1852 obdržel zemské tovární oprávnění k výrobě bavlněného a lněného zboží a uzavřel společenskou smlouvu s vídeňskými velkoobchodníky Ignatzem Schottikem a Heinzem Friedmannem. ${ }^{65}$ Firma vlastnila tovární budovu přímo ve Šternberku, kde bylo v roce 1853 umístěno pět a o tři roky později 150 ručních stavů, mimo prostory továrny pracovalo dalších zhruba 300 stavů. Ročně firma vyrobila na 8000 kusů bavlněného plátna, ložního prádla a pololněného grádlu a 4000 tuctů šátků. ${ }^{66}$

Konkrétnější informace máme k dispozici také ke tkalcovně firmy J. Gromann \& Sohn, která ve Šternberku působila od roku 1833 a byla držitelem jednoduchého továrního

\footnotetext{
$59 \quad$ Bericht... im Jahre 1852, s. 58-73.

60 Bericht... im Jahre 1853. Olmütz 1854, s. 26-61.

61 Srov. JANÁK, Jan: K hodnověrnosti zpráv olomoucké komory o počtu pracovníků při tkaní lnu a bavlny v polovině 19. století. In: Dalši úkoly historiografie lnářství v českých zemích. Lnářský průmysl, suppl. 9. Trutnov 1990, s. 83-90.

62 Bericht... im Jahre 1853, s. 26-61. Do celkového počtu činných osob, resp. stavů byly zahrnuty pouze osoby/ stavy z dominantních bavlnářských okresů, nikoliv z celého obvodu obchodní a živnostenské komory. Zároveň musíme mít na paměti, že šternberští výrobci zadávali práci námezdním tkalcům i mimo vlastní berní okres.

63 TEUCHERT, K.: Die Sternberger Weberei, 4. 6. 1932, s. 1-2.

64 JANÁK, J.: Vlastivěda moravská, s. 109.

65 ZAO-Ol, fond KS Olomouc, sign. Q 1852/59, kart. 174.

66 Tamtéž, fond OŽK Olomouc, inv. č. 1964, 1965, kart. 223.
} 
oprávnění. ${ }^{67}$ Do obchodního rejstříku Krajského soudu v Olomouci byla zaprotokolována $\mathrm{v}$ roce $1854 .{ }^{68}$ Práci majitelé podniku zadávali tkalcům v okolí Šternberka, především v Moravském Berouně, ve Vidlích, Uničově, Dvorcích, Jívové a v Kunicích, kteří pracovali v roce 1855 na 60 , v př́padě zvýšené poptávky na 100 až 200 stavech. V 50. letech podnik ročně vyrobil 10000 kusů tkanin, které putovaly především do Vídně a Uher. ${ }^{69}$ Kromě klasického bavlnářského a lnářského sortimentu se firma zaměřovala i na výrobu nepromokavých plachet pro železniční vagóny a polní sklady, dále na lodní plachtoviny, technické tkaniny využívané v cukrovarech, na oděvy pro horníky a pracovníky na dráze. Za kvalitu svých výrobků byla J. Gromann \& Sohn několikrát oceněna na průmyslových výstavách, např. v Londýně v letech 1852 a 1862, v Mnichově v roce 1854, ve Vídni 1855, 1866 a v roce 1873, v Paříži v roce 1867, o tři roky později ve Štýrském Hradci a v roce 1872 v Moskvě. ${ }^{70}$

Neprríznivá hospodářská situace bavlnářského průmyslu přetrvávala i v 60. letech, zejména $\mathrm{v}$ jejich první polovině v souvislosti s americkou občanskou válkou. Na jejím počátku byla situace šternberského textilního průmyslu ještě relativně příznivá. Zdejší podnikatelé měli ve Šternberku a bližším i vzdálenějším okolí v činnosti na 9000 tkalcovských stavů, na kterých se vyrobilo bavlněné, lněné a směsové zboží v celkové roční hodnotě 3000000 zlatých. ${ }^{71}$ Válečný konflikt ale postupně vyvolal výrazný vzestup cen bavlny a odběratelé brzy pocítili její citelný nedostatek. V důsledku toho rostla cena bavlněné př́ize, která vedla ke zvyšování výrobních nákladů. ${ }^{72}$ Bavlnářská krize vedla k oživení lnářské výroby, jež se načas zbavila konkurence bavlněného zboží a jíž se otevřely nové odbytové možnosti. Vzhledem k velmi torzovitě dochované pramenné základně ale nejsme schopni říci, zdali v samotném Šternberku došlo k nějakému nárůstu produkce čistě Iněných látek. Víme pouze, že řádově několik stovek šternberských tkalců našlo v této době zaměstnání v okolních plátenických oblastech, zejména na Šumpersku. ${ }^{73}$

K výraznému zlepšení situace nedošlo ani ve druhé polovině 60 . let. O stavu šternberského textilního průmyslu nás ve své situační zprávě z roku 1869, kterou vypracoval pro olomouckou obchodní a živnostenskou komoru, informoval továrník Amand Gröger. Ten, jako celá řada dalších šternberských podnikatelů, pocházel ze staré měštanské tkalcovské rodiny. ${ }^{74} \mathrm{Od}$ roku 1832 Amand samostatně provozoval tkalcovské řemeslo. V roce 1849 uzavřel spolu se svým bratrem Johannem společenskou smlouvu, a vznikla tak veřejná obchodní společnost Gebrüder Gröger, která byla u olomouckého krajského soudu zaprotokolována o pět let později. Rodinnému podniku se Amand věnoval až do své smrti v roce $1890 .{ }^{75}$ Byl ale také činný ve veřejném sektoru, mj. v obecním zastupitelstvu, působil ve vedení městské spořitelny a jako předseda místní skupiny německého školského spolku. ${ }^{76}$ Platil za velkého milovníka hudby, pravidelně se ve Šternberku účastnil hudebních

\footnotetext{
Tamtéž, inv. č. 1965, kart. 223; Tamtéž, inv. č. 2533, kart. 279.

68 Tamtéž, fond KS Olomouc, sign. Q 1854/29, kart. 177.

69 Tamtéž, fond OŽK Olomouc, inv. č. 1965, kart. 223.

70 Tamtéž, inv. č. 2533, kart. 279

71 Tamtéž, inv. č. 2315, kart. 253.

72 MYŠKA, M.: Lnářský a bavlnářský průmysl, s. 48-49.

DOHNAL, M.: Průmyslová revoluce, s. 69.

74 MALIVA, Josef: Kurt Gröger : Malba z let 1923/1937. Olomouc 1993, s. 9.

75 ZAO-Ol, fond KS Olomouc, inv. č. 1860, sign. A II 150, kart. 109.

76 Deutsches Volksblatt für Mähren und Schlesien, 22. 3. 1890, s. 6-7.
} 
představení, zvláště těch, která organizovaly hudební spolky z Olomouce, kde měl řadu obchodních kontaktů i přátel. ${ }^{77} \mathrm{~V}$ roce 1871 byl olomouckou obchodní a živnostenskou komorou navržen na člena místní komise pro přípravné práce spojené se světovou výstavou ve Vídni, která se uskutečnila o dva roky později. ${ }^{78}$

Podle Grögrovy zprávy šternberské podniky zabývající se tkaním látek měly tehdy v provozu přibližně 8000 tkalcovských stavů, z nichž na 7540 se vyrábělo bavlněné zboží, popř. směsové tkaniny, na 400 stavech lněné látky a na 60 hedvábný a polohedvábný sortiment. Ne všechny stavy jím započítané se ale nacházely na území berního okresu Šternberk, ale byly rozmístěny i v okolních městech a vesnicích, kupříkladu v Rýmařově, Jamarticích či Ješově. ${ }^{79}$ Celkovou hodnotu roční produkce odhadoval na 7300000 zlatých r. m. Kromě surového lněného plátna se vyráběla také plachtovina, trilich, ryps o šířce $3 / 4$,

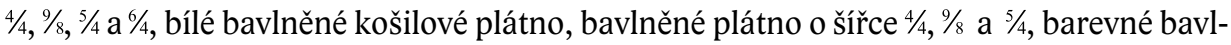
něné ložní prádlo, šatovky, nábytkový ryps a šátky o šiřce $4 / 4,5 / 4$ a $\%$. Vyráběný sortiment byl dále doplněn o bavlněné a směsové žíněnkové látky a nábytkový trilich o šířce $3 / 4,4 / 4$, $5 / 4$ a $\%$, bílé a barevné stuhy a šňůry, celohedvábné a polohedvábné šátky. Gröger ve své zprávě apeloval mj. na nutnost stavby železniční dráhy ze Šternberka do Šumperka a na Olomouc, nebot' její absence výrazně komplikovala rozvoj zdejšího průmyslu. ${ }^{80} \mathrm{~V}$ této době se ale napojení Šternberka na železniční sít již intenzivně řešilo a realizováno bylo na počátku 70. let 19. století. ${ }^{81}$ Zdůrazňoval také nutnost rozvoje odborného školství ve Šternberku, kde většina výrobců trpěla nedostatkem dostatečně kvalifikovaných pracovních sil. ${ }^{82}$

Po překonání hospodářské krize ${ }^{83}$ odstartované krachem vídeňské burzy v roce 1873 , přišlo výraznější oživení šternberského textilního průmyslu v 80 . letech 19 . století v souvislosti se zaváděním mechanických stavů do výroby. Jako první vybudovala na území města v roce 1881 mechanickou tkalcovnu vídeňská firma Ignaz G. Zweig vyrábějící hedvábné zboží (viz níže). V průběhu druhé poloviny 80. a v 90. letech 19. století byly ve Šternberku vystavěny ještě další tři mechanické tkalcovny, a sice firem Heeg \& Friedmann, Gröger, Mikulaschek \& Comp. ${ }^{84}$ a Alexandr Meisel..$^{85}$ Mechanizace výroby ale postupovala poměrně pomalu. Kupř. firma Gebrüder Gröger, která měla v roce 1885 v provozu celkem 175 tkalcovských stavů, dále většinu svého zboží vyráběla na 130 jednoduchých

\footnotetext{
77 Mährisches Tagblatt, 18.3.1890, s. 4.

78 ZAO-Ol, fond OŽK Olomouc, inv. č. 2533, kart. 279.

79 Toto pravděpodobně vysvětluje skutečnost, proč obdobná zpráva vypracovaná firmou J. Gromann \& Sohn pracuje s podstatně nižšími čísly. Pro berní okres Šternberk udává, že zde bylo v provozu 3000 stavů, z nichž na 200 se vyrábělo lněné zboží. Celkovou hodnotu produkce bavlnářského průmyslu v roce 1868 její pracovníci odhadovali na 2160000 zl. r. m.

80 ZAO-Ol, fond OŽK Olomouc, inv. č. 2316, kart. 253.

81 K tomu blíže např. POPELKA, Petr: Zrod moderní dopravy: Modernizace dopravní infrastruktury v Rakouském Slezsku do vypuknutí první světové války. Ostrava 2013.

82 ZAO-Ol, fond OŽK Olomouc, inv. č. 2316, kart. 253. Odborná tkalcovská škola byla ve Šternberku založena $\mathrm{v}$ roce 1873 .

83 Tamtéž, inv. č. 2336, kart. 256.

84 Ke změně názvu Gebrüder Gröger na Gröger, Mikulaschek \& Comp. došlo v roce 1894, kdy se veřejnými společníky rodinné firmy Grögrů stali Franz Mikulaschek a Johann Bokisch. Jejich dosavadní firma Mikulaschek \& Sohn, zaprotokolovaná u olomouckého krajského soudu v roce 1871, vstoupila tímto do likvidace a z obchodního rejstříku byla vymazána v roce 1896. ZAO-Ol, fond KS Olomouc, sign. VII 1871/78, kart. 759; Tamtéž, inv. č. 1860, sign. A II 150, kart. 109.
}

85 STIEF, W.: Topographie der politischen Bezirkes, s. 39-40. 
a 20 žakárových ručních stavech, pouze 25 stavů bylo mechanických. ${ }^{86}$ Pod tlakem modernější a výkonnější konkurence šternberští podnikatelé v této době postupně ztráceli pozice na trzích, přičemž své zboží prodávali téměř výhradně v prostoru habsburské monarchie. Odbytovým problémům se někteří výrobci snažili mj. čelit i tím, že se zaměřovali na tkaní barevných šátků, které zakupovalo převážně venkovské obyvatelstvo. Vzhledem ke značným lokálním odlišnostem v lidovém oděvu bylo potřeba zákazníkům nabídnout širokou paletu vzorů, kterou bylo snazší vyrobit za pomoci ručních nežli mechanických stavů. Ručních stavů se ve Šternberku a okolí v roce 1889 nacházelo na $5000 .{ }^{87}$ Adresár textilního průmyslu z roku 1904 uvádí, že se na území města působilo celkem šest závodů, které při výrobě bavlněného a lněného zboží využívaly mechanického pohonu. ${ }^{88}$

O dalším vývoji šternberského textilního průmyslu, zejména v letech 1900-1918, nemáme kvůli stavu dochované pramenné základny téměř žádné ucelenější informace. Podle sčítání závodů z roku 1902 se na území politického okresu Šternberk zabývalo předením bavlny, v drtivé většině podomácku, 706 osob; tkalcoven bavlny bylo spočítáno 78 s 1115 zaměstnanci, k nimž musíme připočítat dalších 1006 domáckých závodů se 1368 osobami; přádelen lnu a nitáren bylo celkem třináct se 64 zaměstnanci a jedním domáckým výrobcem, samostatných tkalcoven lnu bylo v okrese pouze 94 , a to domáckých se 128 zaměstnanci. ${ }^{89}$

Od roku 1911 byl rakouský textilní průmysl obecně zasažen vleklou krizí, výrazněji umocněnou válečnými událostmi na Balkáně. V obvodu olomoucké obchodní a živnostenské komory většina bavlnářských závodů v roce 1913 vyráběla pouze 50 \% své běžné produkce, o něco př́iznivější byla situace lnářského průmyslu. ${ }^{90} \mathrm{Na}$ Šternbersku byla v roce 1913 téměř úplně zastavena výroba na ručních tkalcovských stavech a počet aktivních mechanických stavů byl snížen o jednu třetinu. Pracovalo se jen čtyři až pět dní v týdnu. ${ }^{91} \mathrm{~V}$ důsledku této krajně nepř́znivé situace firmy propouštěly své dělníky. ${ }^{92}$

Po vypuknutí první světové války došlo k částečnému oživení zdejší textilní výroby především díky armádním zakázkám. Situaci bavlnářského i lnářského průmyslu ale začal velmi brzy komplikovat nedostatek surovin, které byly často nahrazovány papírovou přízí. Problematická a drahá byla železniční doprava a značné potíže způsobovalo zavedení řízeného hospodářství. Již dva roky po vypuknutí války byla kapacita tkalcoven bavlny v obvodu olomoucké obchodní a živnostenské komory využívána z pouhých 10-20 \%.93

ZAO-Ol, fond OŽK Olomouc, inv. č. 7225, kart. 840.

87 Summarischer Bericht der Handels- und Gewerbekammer in Olmütz über die geschäftlichen Verhältnisse in ihrem Bezirke während des Jahres 1889. Olmütz 1890, s. 3.

88 Navíc jsou zde uvedeny továrny firem Franz Langer a Franz Riedl. Adreß-Buch der Textil-Industrie Österreich-Ungarns 1904/1905. Reichenberg 1904, s. 262-264.

89 Österreichische Statistik, Band 75: Ergebnisse der gewerblichen Betriebszählung vom 3. Juni 1902 in den im Reichsrate vertretenen Königreichen und Ländern, 10. Heft: Mähren und Schlesien, Wien 1905, s. 19-20, 84, 93.

90 Summarischer Jahres-Bericht der Handels- und Gewerbekammer in Olmütz über die Tätigkeit der Kammer und die wirtschaftlichen Verhältnisse des Kammerbezirkes im Jahre 1913. Olmütz 1914, s. 104, 117-120.

91 ZAO-Ol, fond OŽK Olomouc, inv. č. 7208, kart. 838.

92 Tamtéž, inv. č. 7207, kart. 838.

93 Summarischer Jahres-Bericht... im Jahre 1916. Olmütz 1917, s. 108. 


\section{Hedvábnický průmysl}

V podstatně menší míře se ve Šternberku rozvíjela výroba hedvábných látek, která se na Moravě začala prosazovat ve druhé polovině 19. století v souvislosti se situací vídeňského hedvábnického průmyslu. Produkce hedvábných tkanin se $\mathrm{v}$ habsburské monarchii zpočátku soustředila především v hornoitalských provinciích (zejména ve městě Gorizia a okolí) a v jižním Tyrolsku, ${ }^{94}$ odkud řada výrobců v průběhu 18 . století odcházela do Vídně, jež si postupem času vydobyla postavení dominantního centra tohoto odvětví v Rakousku. ${ }^{95}$ Značného rozmachu dosáhlo hedvábnictví zejména ve 20. letech 19 . století poté, co se zdejším výrobcům podařilo překonat hlubokou krizi vyvolanou vleklými válkami s revoluční Francií a umocněnou státním bankrotem v roce $1811 .{ }^{96} \mathrm{Ve} 40$. letech ve Vídni pracovalo již více než 500 producentů, kteří zhotovovali širokou škálu zboží, z něhož se zvláště prosadily hedvábné stužky, zlatě a stříbrně brožované církevní tkaniny a nábytkové látky, lemovky a prýmky. ${ }^{97}$

Do poloviny 19. století byla zdejší výroba do velké míry roztříštěna do závodů malého rozsahu, které byly ještě stále svázány cechovními zvyklostmi a povětšinou vybaveny pouze ručními stavy. ${ }^{98}$ Jejich omezená schopnost konkurovat na světovém i domácím trhu francouzské, italské či švýcarské produkci se naplno projevila v 50. letech 19. století. $\mathrm{V}$ roce 1852 byla provedena reforma celních tarifů, která otevřela rakouský trh zahraničním, technicky lépe vybaveným výrobcům, jejichž konkurenci začaly rychle podléhat především drobné, finančně nejhůře zajištěné podniky. ${ }^{99}$ Nepříznivou situaci komplikoval také nárůst cen surového hedvábí na světových trzích stejně jako cen potravin a s ním provázané zvyšování mezd vídeňských dělníků. ${ }^{100}$

Východiskem $\mathrm{z}$ této svízelné situace se pro značnou část větších a kapitálově silnějších podnikatelů stalo přenesení výroby, popř. i sídla firmy do provinčních průmyslových oblastí monarchie, zejména do českého a moravského pohraničí. Zde se v důsledku krize plátenické výroby nacházel dostatek levné, ale zároveň kvalifikované pracovní síly. ${ }^{101}$ První závody zhotovující hedvábné látky vznikaly především v Moravské Třebové, Moravské Chrástové, Rýmařově či Jihlavě. ${ }^{102} \mathrm{~V}$ obvodu olomoucké obchodní a živnostenské komory se hedvábnické firmy největší měrou koncentrovaly v Šumperku ${ }^{103}$ a Rýmařově,

\footnotetext{
94 BRUSATTI, Alois (Hg.): Die Habsburgermonarchie 1848-1918, 1: Die wirtschaftliche Entwicklung. Wien 1973, s. 200.

95 MATIS, Herbert: Österreichs Wirtschaft 1848-1913 : Konjunkturelle Dynamik und gesellschaftlicher Wandel im Zeitalter Franz Josephs I. Berlin 1972, s. 72, 131-132.

96 MÜHLEDER, Ferdinand: Die Schottenfelder Seidenindustrie 1820-1850. Wien 1952 (nepublikovaná disertační práce), s. 4-6.

97 CHALOUPEK, Günther (Hg.): Wien: Wirtschaftsgeschichte 1740-1938, 1: Industrie. Wien 1991, s. 338.

98 BUJATTI, Franz: Die oestrerreichische Seidenzeug-Industrie. In: Die Gross-Industrie Oesterreichs, IV. Wien 1898 , s. 24.

99 CHALOUPEK, G. (Hg.): Wien, s. 339.

100 BRUSATTI, A. (Hg.): Die Habsburgermonarchie, s. 200.

101 JANÁK, J.: Vlastivěda moravská, s. 114.

102 BUJATTI, F.: Die oestrerreichische Seidenzeug-Industrie, s. 24.

103 V letech 1902-1903 bylo v obvodu olomoucké obchodní a živnostenské komory činných 29 závodů zabývajících se výrobou hedvábného zboží, z nichž osm působilo v Šumperku. K tomu bližze DUBSKÁ, Pavla: Šumperský hedvábnický průmysl v letech 1850-1945/1948. In: MERTOVÁ, Petra - SLABOTíNSKÝ, Radek (eds.): Mapa př́běhů: Industriální dědictví Moravy a Slezska. Brno 2015, s. 59-64.
} 
mimo to ale působily i ve Šternberku a Fulneku, kde se zpočátku zhotovovaly především hedvábné stuhy. ${ }^{104}$

Na základě dochovaného pramenného materiálu můžeme s jistotou říci, že na území města Šternberka se v letech 1850-1918 výrobou hedvábných látek zabývaly celkem tři firmy, ${ }^{105} \mathrm{z}$ nichž pouze jedna (Anton Kümmel, tovární výroba šátků a stuh) byla zapsána do obchodního rejstř́iku vedeného u Krajského soudu v Olomouci. ${ }^{106}$

První zprávy o výrobě hedvábných tkanin na Šternbersku máme z konce 60. let 19. století. Tehdy měli šternberští textilní podnikatelé v provozu přibližně 8000 ručních tkalcovských stavů, z nichž zhruba na 60 se vyrábělo hedvábné a polohedvábné zboží. Tyto stavy se nenacházely pouze na území města Šternberka, ale pracovali na nich tkalci v blízkém i vzdálenějším okolí, mj. v Moravském Berouně, Dvorcích, Budišově nad Budišovkou, Libavé, Dlouhé Vsi, Rýmařově, Jamarticích, Laštanech, Bělkovicích, Konici či Ješově. V roce 1869 se celková hodnota roční produkce na těchto stavech vyrobených šátků odhadovala na $200000 \mathrm{zl}^{107}$

Velký rozmach rakouského hedvábnictví, spojený s postupnou mechanizací, s sebou přinesla 80 . léta 19 . století. V roce 1880 bylo v obvodu olomoucké obchodní a živnostenské komory v činnosti 225 stavů, z toho pouze 35 mechanických. O pět let později zde pracovalo již 795 stavů, z nichž téměř polovina, 350, měla mechanický pohon. V roce 1890, kdy v olomouckém obvodu pracovalo již třináct podniků, poskytujících práci 2891 dělníkům, vzrostl počet mechanických stavů na 752. ${ }^{108}$ Podle sčítání závodů z roku 1902 se na území politického okresu Šternberk nacházelo pět tkalcoven hedvábí s 657 zaměstnanci z celkového počtu 30 závodů s 5372 zaměstnanci v obvodu olomoucké obchodní a živnostenské komory. K tomuto číslu musíme připočítat ještě 135 osob, které byly formálně započítány mezi domácké dělníky. ${ }^{109}$

Zřejmě již od 50. let 19. století ve Šternberku podnikala rodina Antona Kümmela, která se od 30. let 19 . století věnovala výrobě hedvábného zboží ve Vídni. ${ }^{110}$ Šternberská tkalcovna zhotovovala především hedvábné a polohedvábné šátky a stuhy. ${ }^{111}$ Svou činnost zde firma ukončila v roce $1929 .{ }^{112}$

\footnotetext{
104 Summarischer Bericht... während des Jahres 1889, s. 126.

105 Chytilưv úplný adresář Moravy. Brno 1911, s. 883-891; Compass 1913, s. 1998-2004, 2007; STIEF, W.: Topographie des politischen Bezirkes, s. 41. Adresář rakouského textilního průmyslu z roku 1884 uvádí pro Šternberk pouze dvě tkalcovny hedvábí, a sice firmy Heeg \& Friedmann a Norbert Langer \& Söhne. Tyto se však primárně nezabývaly výrobu hedvábných tkanin, ale látek bavlněných, lněných a směsových. Langerové využívali umělého hedvábí ve svých tkalcovnách v Německé Libině a Oskavě až od roku 1925. Naproti tomu adresář textilního průmyslu zroku 1904 již eviduje firmy Alois Hrubý a Ig. G.Zweig. Srov.Adress-Buch der Textil-Industrie Oesterreichs. Reichenberg 1884, s. 32; Adreß-Buch der Textil-Industrie Österreich-Ungarns 1904/1905. Reichenberg 1904, s. $262-264$.

106 ZAO-Ol, fond KS Olomouc, inv. č. 1871, sign. A II 157, kart. 110; ve fondu KS Olomouc můžeme dohledat také spisy dalších dvou firem, jejichž předmětem podnikání byla výroba hedvábných tkanin, tyto ale nebyly nakonec zaprotokolovány - srov. sign. VII 1897/2 (Alois Hrubý), kart. 785; Tamtéž, sign. VII 1897/3 (Ig. G. Zweig), kart. 785 .

107 Tamtéž, fond OŽK Olomouc, inv. č. 2316, kart. 253.

108 BUJATTI, F.: Die oestrerreichische Seidenzeug-Industrie, s. 32-33.

109 Österreichische Statistik, s. 19-20, 84, 93.

110 ZAO-Ol, fond KS Olomouc, inv.č.1871, sign.AII 157, kart.110.Compassyaadresáře textilního průmyslu uvádí rok založení 1836. V soupise vídeňských hedvábnických továrníků je uveden rok 1843. Srov. Verzeichnißder Herren Seidenzeug-, Sammet- und Dünntuch-Fabrikanten in der k. k. Haupt- und Residenzstadt-Wien. Wien 1860, s. 23.

111 Compass 1913, s. 1733.

112 ZAO-Ol, fond KS Olomouc, inv. č. 1871, sign. A II 157, kart. 110; Státní okresní archiv Olomouc (dále SOkA
} 
Obdobně lze předpokládat, že v 60. letech zadávala práci místním tkalcům další vídeňská firma Ignaz G. Zweig, ${ }^{113}$ která v roce 1881 započala se stavbou vůbec první šternberské mechanické tkalcovny látek, ${ }^{114} \mathrm{v}$ níž získalo práci okolo 400 dělníků. ${ }^{115}$ Ignaz Georg Zweig byl v roce 1851 zapsán u vídeňského obchodního soudu jako výrobce hedvábného zboží v Schottenfeldu. ${ }^{116}$ Spolu se svým bratrem Hermannem L. Zweigem, uváděným jako obchodník střižním zbožím v Olomouci, založil v roce 1865 veřejnou obchodní společnost Ignaz Zweig u. Bruder, která ve Šternberku po dobu dvou let provozovala obchod prŕzí. ${ }^{117}$ Po smrti Ignaze G. Zweiga v roce 1911 tkalcovnu převzala společnost s ručením omezeným Sternberger Seidenwarenfabrik. Ta se zaměřovala na výrobu hedvábných a vzorovaných hedvábných látek, selských šátků, látek na dámské blůzy a podšívkoviny, ${ }^{118}$ ale již před první světovou válkou, v době, kdy se rakouský textilní průmysl potýkal s vleklou krizí, musela výrazně omezovat výrobu a v roce 1914 propustila na 200 dělníků. ${ }^{119} \mathrm{~V}$ adresáři textilních firem působících v Československu a v dalších nástupnických státech habsburské monarchie z roku $1923^{120}$ ale již nefiguruje a areál její tkalcovny využívala od roku 1925 společnost Glorith vyrábějící umělou rohovinu. ${ }^{121}$

V roce 1884 zahájil ve Šternberku provoz ruční tkalcovny hedvábí další vídeňský podnikatel, a sice Alois Hrubý, ${ }^{122}$ který zde vyráběl šátky a látky v selském stylu a látky ze surového hedvábí ještě krátce po konci první světové války. ${ }^{123}$

Od počátku 20. století se zdejší a celkově rakouský hedvábnický průmysl dostával pod stále silnější tlak zahraniční, zejména francouzské, švýcarské, italské, ale i německé konkurence. Značný problém představoval nedostatečný počet úpravárenských závodů, které se de facto nacházely pouze ve Vídni, nicméně velkou měrou se zboží nechávalo upravovat v zahraničí. Tím se samozřejmě zvedaly výrobní náklady, které se promítly do výsledné ceny hotové látky, jež se tak, navzdory jisté celní ochraně, obtížně prosazovala i na domácím trhu. ${ }^{124}$ Postupně tedy i šternberské továrny redukovaly výrobu. ${ }^{125}$

První světová válka hedvábnickému průmyslu již vůbec nepřála. Toto odvětví vyrábělo především luxusní spotřební zboží a bylo závislé na dovozu suroviny ze zahraničí. Nemělo tedy válečné výrobě mnoho co nabídnout, snad kromě látek využívaných na výrobu sáčků

Olomouc), fond Archiv města Šternberk (dále AM Šternberk), inv. č. 1228, kar. 169. V 80. letech měla firma přímo ve Šternberku instalováno 55 ručních stavů a pracovalo pro ni 25 mužů a 30 žen.

113 ZAO-Ol, fond KS Olomouc, sign. VII 1897/3, kart. 785.

114 TEUCHERT, K.: Die Sternberger Weberei, 25. 6. 1932, s. 1.

115 BERAN, L. a kol.: Industriální topografie, s. 193.

116 Firmenbuch. Wien 1855, s. 61. Online, cit. 4. 9. 2019, dostupné na https://www.digital.wienbibliothek.at/ wbrobv/periodical/pageview/347314.

117 ZAO-Ol, fond KS Olomouc, sign. VII 1865/34, kart. 754.

118 Compass 1913, s. 2003.

119 ZAO-Ol, fond OŽK Olomouc, inv. č. 7207, kart. 838.

120 Adressbuch der Textil-Industrie der Nachfolgestaaten, s. 368-370.

121 BERAN, L. a kol.: Industriální topografie, s. 193.

122 ZAO-Ol, fond KS Olomouc, sign. VII 1897/2, kart. 785.

123 Compass 1913, s. 2001; Adressbuch der Textil-Industrie der Nachfolgestaaten, s. 369.

124 Summarischer Jahres-Bericht... im Jahre 1911. Olmütz 1912, s. 28-29.

125 Již v roce 1905 chystala omezení výroby jak firma Ig. G. Zweig, tak továrna Antonína Hrubého, která počítala s odstavením 15-20 stavů. SOkA Olomouc, fond AM Šternberk, inv. č. 1228, kar. 169. 
na střelný prach. ${ }^{126}$ Část výrobců v obvodu olomoucké komory také po jistou dobu dodávala tkaniny dámskému konfekčnímu průmyslu, který postupně neměl kvůli potřebám armády k dispozici bavlněné, vlněné a ani lněné látky. ${ }^{127}$

\section{Závěr}

Textilní průmysl představoval do první světové války, resp. po celou první polovinu 20. století nejdůležitější složku hospodářství města Šternberka a jeho okolí. Šternberští tkalci po staletí zpracovávali domácí suroviny, tj. len, v malém množství také vlnu. Na přelomu 18. a 19. století ale započal pokles zdejší lnářské výroby, která poměrně rychle ustupovala tehdy módnímu bavlnářství. Příčiny tohoto procesu můžeme hledat především ve změně poptávky na trzích hotových výrobků, ve vzrůstajících cenách Iněné příze a v poměrně snadném přechodu od lnářské rukodělné tkalcovské technologie $\mathrm{k}$ technologii bavlnářské. Nicméně zpracování lnu z města a okolí zcela nevymizelo, kromě čistě bavlněných látek řada výrobců nadále zhotovovala tkaniny lněné, v podstatně větší míře tkaniny směsové.

Ostatně bavlnářský průmysl se v prostoru Moravy a Slezska, na rozdíl od sousedních Čech, rozvíjel jen velmi pozvolna. V roce 1841 se v Čechách vyrobilo 26 \% předlitavské produkce prríze a $48 \%$ produkce bavlněných látek. Morava se Slezskem se tehdy na celorakouské výrobě tkanin podílely pouze $14,5 \%$ a až do 80 . let 19 . století nebyla na jejich území vybudována významnější přádelna bavlny. ${ }^{128}$ Do poloviny století se zde zformovalo v podstatě sedm bavlnářských oblastí, jež jsme si uvedli výše a které doplňovaly menší distrikty v západní části Moravy. ${ }^{129}$ Bavlna pronikala do Šternberka a okolí prakticky ve stejné době jako např. do severovýchodních Čech, ${ }^{130}$ nicméně se zdá, že rozvoj zdejšího bavlnářského průmyslu neprobíhal příliš dynamicky. V první polovině 50 . let 19 . století se na Šternbersku vyrobilo zhruba $9 \%$ úhrnné hodnoty bavlnářského průmyslu v obvodu olomoucké obchodní a živnostenské komory, ${ }^{131}$ největší podíl, tj. 30-40 \%, připadl na Místecko, kde se výroba bavlněných látek začala rozvíjet od přelomu 20. a 30. let 19. století. ${ }^{132}$

Stejně jako na Šternbersku ani zde nebyla konverze k bavlnářství spojena s přechodem ke strojové výrobě a tovární organizaci práce. Jistý rozdíl ve vývoji obou oblastí můžeme ale vidět např. v tom, že na Místecku se na rozdíl od Šternberska podíleli na nákladnickém podnikání ve větším měřítku židovští obchodníci a že klíčovým odvětvím místeckého bavlnářského průmyslu se stalo úpravnictví, z něhož vycházela většina impulsů $\mathrm{k}$ dalšímu rozvoji tkalcovství. ${ }^{133} \mathrm{O}$ apretačních provozech působících ve Šternberku máme pro celé 19. a první polovinu 20. století jen velmi málo, navíc značně útržkovitých informací.

\footnotetext{
126 Summarischer Jahres-Bericht... im Jahre 1914. Olmütz 1915, s. 117.

127 Summarischer Jahres-Bericht... im Jahre 1915. Olmütz 1916, s. 130.

128 MYŠKA, Milan: Bavlnářský průmysl v Evropě a v zemích habsburské monarchie v době založení maloskalické přádelny. In: ZÁŘICKÝ, Aleš a kol.: Milan Myška :Z díla hospodářského historika. Ostrava 2010, s. 292.

129 JANÁK, J.: Vlastivěda moravská, s. 108.

130 HLADKÝ, Ladislav: Vývoj bavlnářství v severovýchodních Čechách do první světové války. In: I. setkání, s. 26-65.

131 Bericht... im Jahre 1852, s. 58-73. Pro doplnění uved'me, že v př́ípadě lněných a pololněných tkanin se jednalo cca o $11 \%$.

132 MYŠKA, M.: Lnářský a bavlnářský průmysl, s. 164.

133 Tamtéž, s. 165.
} 
Amand Gröger ve své zprávě pro olomouckou obchodní a živnostenskou komoru z roku 1881 uvedl, že se ve městě nachází šest bělidel, osmnáct barvíren a tři tiskárny, které ale fungují jako pomocné provozy zdejších tkalcoven, a že část zboží se prodává neapretovaná. Johann Belleda, o němž víme pouze to, že se v této době věnoval úpravě tkanin, udal šest bělidel, 20 barvíren a dvě úpravny. ${ }^{134} \mathrm{Z}$ přelomu století pak známe pouze jména některých podnikatelů, popř. jejich firem (např. Ferd. Fabritz \& Söhne, Franz Fiedler, Johann Belleda, Alois Belleda, Karl Lamich).

Na počátku 70. let 19. století došlo k výraznému zlepšení podmínek pro podnikání, když byl Šternberk propojen železnicí s Olomoucí a později také s Hanušovicemi, Šumperkem a Dolní Lipkou. ${ }^{135}$ Trvalo dalších deset let, než byla ve městě zprovozněna první mechanická tkalcovna, v níž se ale nezpracovávala bavlna ani len. Jednalo se totiž o tkalcovnu hedvábí vídeňské firmy Ignaz G. Zweig, která se řadila mezi tři hedvábnické podniky, jež na území města prokazatelně působily od 60 . let 19 . století. ${ }^{136} \mathrm{Na}$ Místecku tehdy provozovalo strojní tkalcovny bavlny již pět podniků a soustředilo se zde 57 \% všech bavlnářských strojních stavů z obvodu olomoucké obchodní a živnostenské komory. ${ }^{137} \mathrm{Ve}$ stejné době se v Šumperku vyráběly lněné, bavlněné a hedvábné tkaniny v šesti mechanických tkalcovnách. ${ }^{138}$ Ve Šternberku, na rozdíl od Šumperka či Místku, také nikdy nevznikla strojní přádelna bavlny či lnu.

Na přelomu století již bylo zjevné, že se zde nepodařilo prosadit mechanizaci výroby takovou měrou jako v jiných, více prosperujících textilních regionech v obvodu olomoucké obchodní a živnostenské komory, byt' jak pro Místecko, tak Šumpersko platí, že se zde vedle postupně se rozšiřující tovární strojové výroby velmi dlouho udržovala výroba rukodělná, díky níž mohli podnikatelé rychle a bez větších investic reagovat na měnící se poptávku. ${ }^{139}$ Největší šternberská firma Norbert Langer \& Söhne v souvislosti s mechanizací přesunula svou výrobu mimo město, celá řada dalších závodů setrvávala u ručního tkaní. Pomineme-li hedvábnické továrny, pro něž byla charakteristická větší koncentrace výroby, ${ }^{140}$ zaměstnávala tak v průměru jedna firma věnující se v roce 1902 na území politického okresu Šternberk tkaní bavlny čtrnáct osob. ${ }^{141}$

Značná torzovitost dochovaného pramenného materiálu nám neumožňuje udělat si detailnější představu o stavu a vývoji šternberského textilního průmyslu ve druhé polovině 19. a na počátku 20. století. Zcela nám chybí údaje o objemech výroby, ročních obratech, konkrétním vyráběném sortimentu, cenách výrobků, obchodních kontaktech, finančních zdrojích, investicích, osazenstvu či technickém zázemí jednotlivých firem. Sjistotou můžeme pouze říci, že zdejší textilní průmysl v tomto období čím dál více podléhal kvalitnější a levnější zahraniční konkurenci, pravděpodobně ale i konkurenci domácí.

\footnotetext{
134 ZAO-Ol, fond OŽK Olomouc, inv. č. 7245, kart. 841.

135 POPELKA, P.: Zrod, s. 136.

136 Jen pro ilustraci dodejme, že první strojní tkalcovna v českých zemích (mladoboleslavských podnikatelů Köchlina a Singera) zahájila svůj provoz na počátku 30. let 19. století.

137 MYŠKA, M.: Lnářský a bavlnářský průmysl, s. 100.

138 TURKOVÁ, Hana: Významné objekty textilního průmyslu na území města Šumperka. Památková péče na Moravě - Monumentorum Moraviae tutela, 2008, č. 14, Technické památky, s. 23-28.

139 MYŠKA, M.: Lnářský a bavlnářský průmysl, s. 166.

140 Podle sčítání živnostenských závodů v roce 1902 zaměstnával největší počet tkalcoven hedvábí v obvodu olomoucké komory mezi 101 a 300 zaměstnanci.

141 Österreichische Statistik, s. 19-20, 84, 93.
} 
Cestu, jak rozšířit naše dosavadní poznatky, by mohl představovat výzkum jednotlivých podnikatelských rodin, jejich sociální mobility, veřejného angažmá apod., stejně jako studium stavu a vývoje domáckého průmyslu v této oblasti, obé však bude dochovanou pramennou základnou značně limitováno.

\section{Summary}

\section{Outline of the Development of the Textile Industry in Šternberk in the Years 1850-1918}

For centuries, the town of Sternberk was closely associated with textile production which was an important part of the town's economy until the middle of the $20^{\text {th }}$ century. The local textile production was traditionally dominated by linen which prevailed until the end of the $18^{\text {th }}$ century. However, from the beginning of the $19^{\text {th }}$ century, the sales of Sternberk linen fabrics were increasingly threatened by competition from cotton fabrics which were more practical and affordable. In 1802, the Pawlik brothers, master weavers, were the first to have English cotton yarn imported to Sternberk. Gradually, more and more weavers switched to the production of cotton fabrics. In addition to pure cotton fabrics, many of them also produced blended fabrics (with the addition of linen yarn). The second half of the $1820 \mathrm{~s}$ brought a significant boom to the local cotton industry. Several innovations were introduced into the production process and Šternberk became one of the most important centres of this industry in Moravia. In the 1850s, the production of the Sternberk cotton district accounted for 9\% of the total volume of fabrics produced in all cotton districts of the Olomouc Chamber of Commerce and Trade, employing $24 \%$ of workers and weaving on $19 \%$ of the total number of looms. At the end of the 1860s, Sternberk companies operated approximately 8,000 looms, some of which were located outside the tax district, for example in Rýmařov, Jamartice or Ješov. At that time, the production of silk fabrics was already developing in Sternberk. It was organized by Viennese entrepreneurs in an effort to cope with rising production costs. After overcoming the economic recession started by the collapse of the Vienna Stock Exchange in 1873, there was a significant revival of the Sternberk textile production in the 1880s in connection with the introduction of mechanical looms into production. By the end of the $19^{\text {th }}$ century, four mechanical weaving mills had been built in the town. However overall, mechanisation progressed too slowly and local companies were losing positions not only in the foreign but also in the domestic market under the pressure of more modern and efficient competition. The situation was further exacerbated by the protracted crisis which the Austrian textile industry faced since 1911. After the outbreak of the First World War, Sternberk textile entrepreneurs had to deal with a shortage of raw materials, skilled workforce and difficult transport conditions. The source material is only fragmental and does not allow us to get a more detailed idea of the state and development of the Sternberk textile industry in the period under review. We do not have data on production volumes, annual turnovers, business contacts, financial resources or technical background of the individual companies. A possible way to increase our current knowledge could be to conduct research focusing on the local families of entrepreneurs. However, even such a research would probably be considerably limited by the preserved sources. 